\title{
Mathematics Learning Based Islamic Economy Using Mind Map Painting
}

\author{
Farida Esti Widayati, ${ }^{\mathrm{a}, *}$ Ayuk Nur Sholikhah, ${ }^{\mathrm{b}}$ Ade Prabowo, ${ }^{\mathrm{c}}$ Muhammad Nizam, ${ }^{\mathrm{d}}$ \\ ${ }^{a}$ Mathematics teacher of Al Firdaus High School, Sukoharjo, Indonesia. \\ ${ }^{b}$ Students of Mathematics Education, Postgraduate, UNS, Indonesia. \\ ${ }^{c}$ Students of Mathematics Education, Postgraduate, UNS, Indonesia. \\ ${ }^{d}$ Lecturer, UNS, Indonesia. \\ *Corresponding author: faridaesti27@gmail.com
}

\begin{abstract}
Article history
Received: 10/10/2016

Received in revised form: 14/01/2017

Accepted: 04/03/2017

Abstract

This paper describes about a mathematics learning based on figh (Islamic economic) and assisted by mind map painting. The learning objectives of this paper are not only to construct students' knowledge of learning materials, but also inculcate moral values based on the science of fiqh (Islamic economic). It is as stated in the national learning goals is to establish the appropriate nature of religious norms, knowledgeable and creative. One of the mathematics instructional materials contained in the science of fiqh (Islamic economic) is a social arithmetic. In this paper,it is asocial learning arithmetic using mind map painting. Mind map painting capable of developing the mind and improving the memory. Moreover, mind map painting capable of improving the absorption of information, problem solving and increase ability to think. Syntax learning in this paper, namely, 1) the opening, starting together to read and understand the gist of one letter of the Qur'an, 2) the core activities, the provision of video illustration initial problems, the provision of material and finish problem of the video, create a mind map painting and present it to the class, 3) cover, giving feedback on the presentations and jointly concluded learning outcomes. So the learning mathematics based on Islamic economy using mind map painting is expected to construct students' knowledge and foster the student's character based on the science of fiqh (Islamic economic).
\end{abstract}

Keywords: mathematics learning, islamic economic, mind map painting 


\subsection{INTRODUCTION}

Islam is a way of human's life because it covers all aspects of life. Islam is a religion and a proper system guiding life. Completeness of coverage aspect of Islamic life is mentioned in detail in the Qur'an such as belief, morals, behavior, feelings, education, social, political, economic, military and law. Islam teaches the human how to do education and teaching. One verse of the Qur'an that instructs Muslims to learn is Surat Al Mujadilah verse 11 which means $O$ you who believed, when you are told, "Space yourselves" in assemblies, then make space; Allah will make space for you. And when you are told, "Arise," then arise; Allah will raise those who believed among you and those who were given knowledge, by degrees. And Allah is Acquainted with what you do.Besides that,economics is very important aspect in Islam. Economics objectives in Islam or so-called Shariah economics is that prosperity community can be realized. Therefore, the rules of the economy in Islam contain riba, business debts, writing in commerce, and others.

As a knowledge, Shariah economy in general is often interpreted as a social science that studies the problems of a people's economy based on the values and ethics of Islam. The main Islamic economic philosophy emphasizes partnership and togetherness in profits, as well as the risk of a more fair and transparent. Shariah economy was also accepted and practiced by Muslim communities where they become a minority, in England in 2004 established the Islamic Bank of Britain, which marks the beginning atmosphere of Islamic economic system in Europe, the British government wants to become a center for Islamic finance. Moreover in some European countries has also been applied economic Shariah principles although not using the name of sharia. Shariah economy which has also been officially recognized by the World Bank and make it as a priority area in the program's financial sector that give more profit and justice, compared with the capitalist economic system that is inherently present.

Shariah economy is a broad term and it does not only apply to Islamic financial business. Islamic economic system is different from the system of capitalist economic, socialist and communist. Islamic economic not in the middle of them. Islamic economic system which proved immune to the crisis needs to be socialized from an early age, that since the students in the school. The signs of that period should be addressed by the authorities such as the Ministry of Education and Culture, Local Government and Schools, to review the lessons in school, such as mathematics learning. In the curriculum, in addition to mathematics, there is also a figh learning that discuss about buying-selling and profit-sharing. The material that closely related to the mathematical material that social arithmetic.

Social arithmetic is a junior mathematics material that discuss the economic activity associated with buying-selling, profit-loss, savings, tax, and others. Sale and purchase are an inseparable part of the daily life of every person. In addition, for students to be more familiar with contract-business contract in Islam, then they need to be introduced on a revenue sharing system. There are a lot of values in sharia economy that students need to have such as an honest, trustworthy, sincere, generous, tawadhu, establish relationships, relationships with family, relationships with parents, stay away from doubtful and illegitimate business, amar ma'ruf nahi munkar, work hard and others. Those values can also be applied to the social arithmetic material.

On implementation, the social arithmetic learning difficulties occur because of erroneous teaching methods, where math is not subject to reason but to memorize. Additionally, the cause of difficulty learning mathematics in students is due to the learning of mathematics is less meaningful. According to Van de Henvel-Panhuizen, when children learn mathematics separate from their daily experiences, the child will quickly forget and cannot apply mathematics. Based on these opinions, learning mathematics emphasized the linkage between mathematical concepts with children everyday experience. The need to implement the concept of mathematics which has been wholly owned subsidiary in everyday life or in other areas is very important. Thus, it the required learning strategy or media that can help children understand and associate the real-life experiences of children with mathematical ideas for meaningful learning.

One of the strategies that favored the child is using the computer and the image media is mind map painting. Mind map painting is maid map presented in the form of paintings. While mind mapping is a 
technique of take note that is able to develop the mind and improve memory because the information compiled branching from the main themes that include images, symbols, colors and text. The use of a mind map painting on mathematics learning is expected to provide meaningful learning in children so that they can improve thinking ability and creativity. In addition, the learning of mathematics based on sharia economy is expected to assist students in understanding the laws of Shariah in the sale and purchase and economic activity in our daily lives.

\subsection{METHODOLOGY}

Studies in this paper uses literature study. Literature is a way of solving problems by tracing the ancient sources that have been made previously. Kind of literature used in this paper is the literature of primary and secondary literature. Primary literature are works of original writing which contains a study on new theory, or explanation of an idea in various fields. While the secondary literature is literature that contains information about the primary literature. Secondary literature offers primary literature by way of summarizing index, so the secondary literature does not contain new knowledge, but merely repeating and organize existing knowledge.

\subsection{SALE AND PURCHASE IN ISLAM}

In this study, sharia economics is limited to the sale and purchase of sharia. This restriction is based on a junior high school math curriculum materials related to sharia economics is a social arithmetic, ie: sale and purchase.

Sale and purchase by language means the exchange or mutual exchange. Meanwhile, according to the understanding of jurisprudence, purchases are to exchange goods with other goods in harmony and with certain requirements. Sale and purchase can also be interpreted to exchange money with the desired goods in accordance with the pillars and specific terms. Once the purchase is done legally, goods sold belong to the buyer, while money paid by buyers as a substitute for the price of goods, belong to the seller (Khursid Ahmad: 1999).

Once when the Prophet Muhammad was asked by a friend about the job best. He said, the best job is a job done with his own hands and purchases are done well. Sale and purchase should be done by traders who understand the science of jurisprudence. This is to prevent fraud from both sides. Caliph Umar bin Khattab, very concerned about buying and selling in the market. He evict traders who do not have knowledge of the science of jurisprudence for fear of buying and selling that do not comply with Islamic law (Rammal, 2007).

At the present time, how to make buying and selling experience development. At the supermarket or the mall, shoppers can select and take the needed goods without dealing with the seller. Statement of the seller (ijab) was realized in the list price of the goods or the price tag on the goods sold while buyer's statements (qobul) in the form of actions buyer pays for the goods taken.

Sale and purchase has been used since, although the shape is different. Sale and purchase of well justified and valid since the time of Prophet Muhammad SAW till now. Sale and purchase have evolved along thinking and fulfillment of human needs. Sale and purchase of existing in society among which are: a) buying and selling barter (exchange of goods with goods); b) money charger (currency exchange); c) purchase in cash (directly paid in cash); d) sale and purchase in installments (credit); e) purchase by way of auction (offered to the general public to get the highest price).

Many forms of trading should be done according to the laws of buying and selling in the Islamic religion. Legal origin of buying and selling is permissible (allowed). Allah has permitted trading practices and in accordance with his shari'ah. In Surah al-Baqarah verse 275 Allah says:

... And Allah has permitted trading and forbidden usury ... (Q.S. Al-Baqarah: 275)

Sale and purchase must not conflict with Islamic religious law. The principle of buying and selling in Islam, should not be detrimental to either party, either the seller or the buyer. Sale and purchase must be made on the basis of consensual, not compulsion. This is explained by Allah in Surah an-Nisa verse 29 which means: 
O ye who believe! Squander not your wealth among yourselves in vanity, except it be a trade by mutual consent, and kill not one another.

"O you who believe! do not devour your property among yourselves falsely, except that it be trading by your mutual consent; and do not kill your people; surely Allah is Merciful to you." (QS. An-Nisa: 29)

In a hadith of the Prophet SAW, from Abu Sa'id al-Khudri said, the Prophet SAW said: actually buying and selling is based on mutual sincerity. (H.R. Ibn Maajah).

Sale and purchase are considered valid if it meets the pillars and terms of sale and purchase. The pillar of purchase means something that must exist in buying and selling. If one of the pillars of buying and selling is not met, then the purchase cannot be done. According to most scholars, there are four type of sale and purchase pillar, such as:

a. Seller and buyer

b. Items for sale

c. Legal tender (money)

d. Ijab Qabul

Ijab is the word of the seller in offering merchandise, for example: "I sell this stuff for Rp 5,000.00". While qabul is the word of the buyer to receive purchase, for example: "I bought it for USD \$ 5000.00 stuff". Imam Nawawi argues, that ijab and qobul not be spoken, but according to the customs that have been in effect. This is in accordance with the sale and purchase transactions that occurred today in the supermarket. Buyer is sufficient to take the necessary goods were then taken to the cashier to pay.

\subsection{MIND MAP PAINTING}

Brinkmann (2003: 36) states that "Mind Mapping was firstly developed by Tony Buzan, a mathematician, psychological and brain researcher". Mind mapping was first developed by Tony Buzan is a mathematician, psychologist and researcher. According to Buzan (2007), mind mapping is a technique to take note that capable of developing the mind and improve memory because the information compiled branching from the main themes that include images, symbols, colors and text. Likewise, Adolo (2013) explains that mind mapping can improve absorption of information, problem solving and increased ability to think. So with mind mapping students' ability to think, absorb information, solve problems, and since it can be increased.

There are several steps in making mind mapping. Among them according to Buzan (2013: 15-16) is as follows:

a. Starting from the middle of blank paper with its longest side placed horizontally due to start from the middle of the paper surface will provide breadth to the way the brain works scatter in all directions and create yourself more freely and naturally.

b. Use an image or photograph to the idea because is worth a thousand words and helps the students to use their imaginations to make fixed focus, concentrate and make the brain more active and busy.

c. Use colors because colors make mind mapping looks more cheerful, add energy and life, enhancing the powerful force for creative thinking and also a fun thing.

d. Connect the main branches to the central image and connect the branches of second and third levels at the first and second and so on.

e. Draw connecting lines that curved instead of straight line due to the straight lines will make the brain dull. Our brains are much more interested in curved lines as we find in nature.

f. Use one keyword for each line for single keywords will give more power and flexibility. Each keyword will be more able to express new thought.l

g. Use images as an images and symbols are easy to remember and stimulate new and creative associations.

Mind map painting is the development of mind mapping. Mind map painting was introduced in Indonesia by Erika Oktarini in 2012. This mind map painting is basically a mind mapping presented in the form of paintings. In contrast to the mind mapping in general, using colors, images, or simple photos, mind map 
painting is more expressive and varied according to the artist's viewpoint. Therefore, the mind map painting not only improve the ability to think, but also promotes creativity. Erika Oktarini and Abdul Gafur (2013) said if the used of video mind map painting resulted in learning improvement as much as $44,36 \%$, gained from the gain score mean. Here are some examples mind map painting

\section{Figure1. Example of Mind Map Painting}

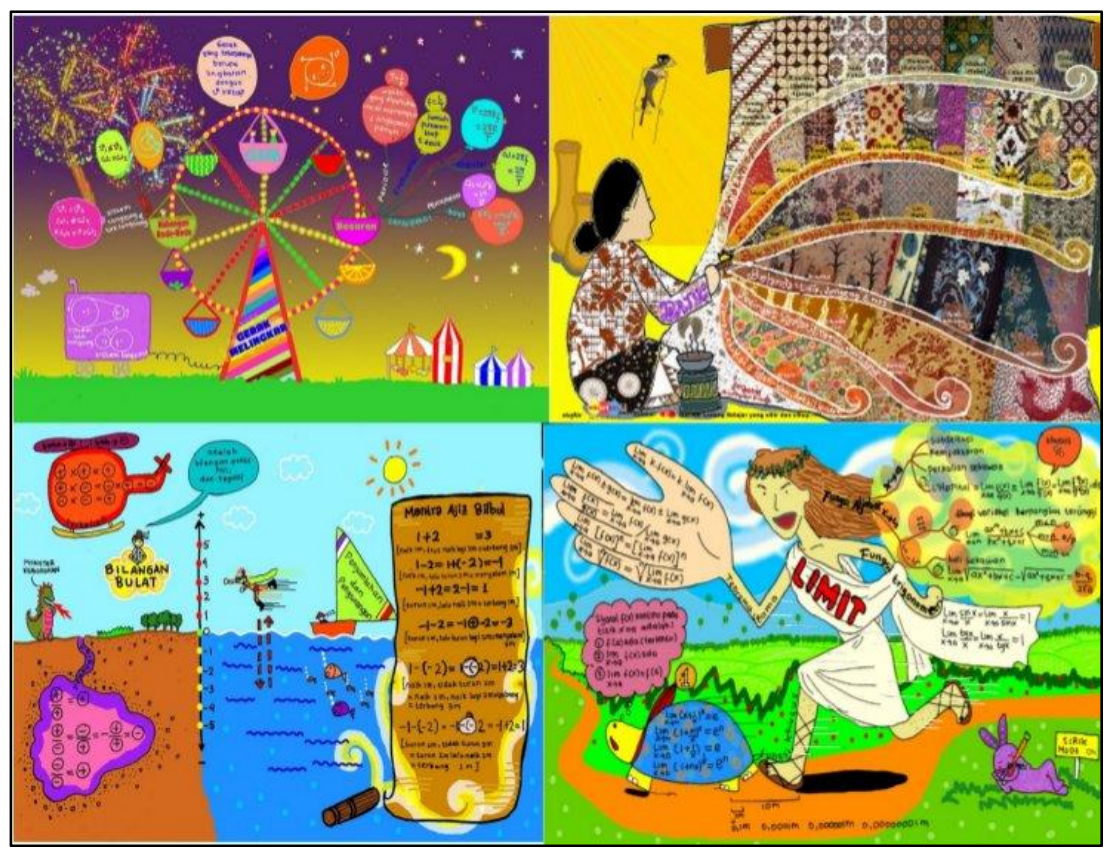

\subsection{LEARNING MATHEMATICS BASED ISLAMIC ECONOMY USING MIND MAP PAINTING}

Based on the discussion above, mathematics learning in this paper are based on the science of fiqh and sharia economy aided the mind map painting. In the process of learning to use the principles and science of fiqh. In this paper, while some learning syntax is described in the following table.

Table 1. Syntax of Learning Mathematics Based Islamic Economy Using Mind Map Mapping

\begin{tabular}{|c|c|c|c|}
\hline No & $\begin{array}{l}\text { Learning } \\
\text { Activities }\end{array}$ & Teacher Activities & Student Activities \\
\hline \multirow[t]{3}{*}{1} & \multirow[t]{3}{*}{ Preliminary } & Pray together before the start of learning. & Pray together before the start of learning. \\
\hline & & $\begin{array}{l}\text { Directing the students to recite the Qur'an Surah } \\
\text { An Nisa verses } 29 \text { and understand its meaning. }\end{array}$ & $\begin{array}{l}\text { Reading the Qur'an Surah An Nisa verses } \\
29 \text { and understand its meaning. }\end{array}$ \\
\hline & & $\begin{array}{l}\text { Provide stimulus on the core of the Qur'an } \\
\text { Surah An Nisa verses } 29 \text { and give feed back on } \\
\text { what students. }\end{array}$ & $\begin{array}{l}\text { Provide arguments about the core of the } \\
\text { Qur'an Surah An Nisa verse } 29 .\end{array}$ \\
\hline \multirow[t]{7}{*}{2} & \multirow[t]{7}{*}{$\begin{array}{l}\text { Core } \\
\text { Activities }\end{array}$} & $\begin{array}{l}\text { Viewing video illustration of the problems } \\
\text { related to gains and losses in our daily lives. }\end{array}$ & $\begin{array}{l}\text { Pay attention and watch the video } \\
\text { illustration of the problems related to the } \\
\text { profit and loss in daily life. }\end{array}$ \\
\hline & & $\begin{array}{l}\text { Instruct students discuss to find out the } \\
\text { problems that exist in the illustration video. }\end{array}$ & $\begin{array}{l}\text { Discuss find out the problems that exist in } \\
\text { video illustration. }\end{array}$ \\
\hline & & Ask a few students to express their opinions. & Presenting the opinion. \\
\hline & & $\begin{array}{l}\text { Provide feedback on students' opinions } \\
\text { expressed. }\end{array}$ & $\begin{array}{l}\text { Listen to the feedback given by the } \\
\text { teacher. }\end{array}$ \\
\hline & & $\begin{array}{l}\text { Provide relevant materials to solve existing } \\
\text { problems in the video illustrations. }\end{array}$ & $\begin{array}{l}\text { Taking into account the explanations } \\
\text { given by the teacher. }\end{array}$ \\
\hline & & $\begin{array}{l}\text { Instruct students to solve existing problems in } \\
\text { the video illustration. }\end{array}$ & $\begin{array}{l}\text { Resolving the problems that exist in the } \\
\text { video illustrations. }\end{array}$ \\
\hline & & Discusses problem solving of video illustration. & $\begin{array}{l}\text { Pay attention the discussion of teachers } \\
\text { regarding the settlement of the existing }\end{array}$ \\
\hline
\end{tabular}


Farida Esti Widayati et. al. / UMRAN - International Journal of Islamic and Civilizational Studies. Vol.4, no.1-1, pp. 41 - 47

\begin{tabular}{|l|l|l|l|}
\hline No & \multicolumn{1}{|c|}{$\begin{array}{l}\text { Learning } \\
\text { Activities }\end{array}$} & \multicolumn{1}{|c|}{ Teacher Activities } & \multicolumn{1}{c|}{ Student Activities } \\
\hline \multirow{2}{*}{3} & & $\begin{array}{l}\text { Provide instruction to students to create a mind } \\
\text { map painting of the material that has been } \\
\text { studied. }\end{array}$ & $\begin{array}{l}\text { Make a mind map painting based on } \\
\text { materials that have been studied. }\end{array}$ \\
\cline { 3 - 4 } & $\begin{array}{l}\text { Ask some students to present mind map } \\
\text { painting that was created in front of the class. }\end{array}$ & $\begin{array}{l}\text { Presenting a mind map painting that was } \\
\text { created in front of the class. }\end{array}$ \\
\hline 3 & $\begin{array}{l}\text { Closing } \\
\text { Activities }\end{array}$ & $\begin{array}{l}\text { Provide feed back from the presentations that } \\
\text { have been submitted student. }\end{array}$ & $\begin{array}{l}\text { Listen, record and respond to the feedback } \\
\text { that has been conveyed by the teacher. }\end{array}$ \\
\cline { 3 - 4 } & $\begin{array}{l}\text { Guiding the students deduce lessons learned } \\
\text { have been implemented and provide } \\
\text { reinforcement material sharia-based economy }\end{array}$ & $\begin{array}{l}\text { Summing learning has been implemented } \\
\text { and attention to strengthening the } \\
\text { material-based sharia economy }\end{array}$ \\
\cline { 3 - 4 } & Pray together to end learning. & Pray together to end learning \\
\hline
\end{tabular}

The material raised in this lesson is a social arithmetic. Social arithmetic is one of the materials in junior secondary schools that discusses the activities related to the economy, such as buying and selling, profit and loss, tax and others. Character values contained in the activity associated with economic such as an honest, trustworthy, tawadhu ', amar ma'ruh nahi munkar, hard work and much more.

\subsection{CONSLUSION}

Mathematic learning based Islamic economy using mind map painting is a mathematic learning that based on fiqh (islamic economy) and using mind map painting for learning models. Laerning objectives that can be achieved not only knowledge contructing about the material, but also moral fostering based on fiqh (islamic economic). Moral values embodied in it based on verses in Qur'an, namely Surah An-Nisa verse 29 and Al-Baqarah verse 275. Mathematic learning based islamic economy using mind map painting assisted with instructional video. Syntaxs in mathematic learning based Islamic economy using mind map painting are as follows:

1. The opening, starting together to read and understand the gist of one letter of the Qur'an,

2. The core activities, the provision of video illustration initial problems, the provision of material and finish problem of the video, create a mind map painting and present it to the class,

3. Cover, giving feedback on the presentations and jointly concluded learning outcomes.

\section{References}

Adodo, S. O. (2013). Effect of Mind Mapping as a Self-Regulated Learning Strategy on Students Achievement in Basic Science and Technology. MCSER-CEMAS Vol.4, No.6. Roma: Sapienza University of Rome.

Brinkman, A. (2003). Graphical Knowledge Display-Mind Mapping and Concept Mapping as Efficient Tools in Mathematics Education. Mathematics Education review: 35-51.

Buzan, T. (2007). Mind Map: Untuk Meningkatkan Kreativitas. Jakarta: Gramedia Pustaka Utama.

Buzan, T. (2013). Buku Pintar Mind Map. Jakarta: PT Gramedia Pusat Utama.

Khursid Ahmad. (1999). Islamic Finance and Banking : The Challenge of the 21st Century, dalam Imtiyazuddin Ahmad (ed.) Islamic Banking and Finance : The Concept, The Practice and The Challenge. Plainfield. The Islamic Societyof North America.

Nu'man, Mulin. (2015). Pengembangan Bahan Ajar Matematika Berbasis Ekonomi Syariah untuk Madrasah Tsanawiyah. Jurnal Fourier Vo.4, No. 2: 168-186. 
Oktarini, Erika. (2013). Kompasiana. http://kompasiana.com/education.blogspot.com/apa-itu-mind-mappainting552016288133116c709de546.

Oktarini, Erika and Abdul Gafur. (2013). Formative Evaluation on Majoe Djaya Instructional Video Produced by Eduartion. Jurnal Inovasi Teknologi Pendidikan Vol 1(1): 40 - 48

Rammal, H. G., Zurbruegg, R. (2007). Awareness of Islamic Banking Products Among Muslims : The Case of Australia. dalam Journal of Financial services Marketing, 12 (1), 65-74. 